\title{
ISOLATION OF ARTONIN E FROM THE ROOT BARK OF ARTOCARPUS RIGIDA, SYNTHESIS OF ARTONIN E ACETATE AND EVALUATION OF ANTICANCER ACTIVITY
}

\author{
Tati Suhartati $^{1^{*}}$, Hernawan ${ }^{1}$, Jhons F. Suwandi $^{2}$, Yandri ${ }^{1}$ and Sutopo Hadi ${ }^{1 \#}$ \\ ${ }^{1}$ Department of Chemistry, University of Lampung, Jl. S. Brojonegoro No. 1, \\ Bandar Lampung, Indonesia 35145 \\ ${ }^{2}$ Faculty of Medicine, University of Lampung, Jl. S. Brojonegoro No. 1, \\ Bandar Lampung, Indonesia 35145
}

tati.suhartati@fmipa.unila.ac.id,sutopo.hadi@fmipa.unila.ac.id

\begin{abstract}
Artonin E was isolated from the root bark of A. rigida. The isolated compound was then esterified using a known procedure by the addition of acetic anhydride with pyridine catalyst. The structure of the synthesized compound was carefully determined by physical and spectroscopic techniques and compared to the data in the literature. The anticancer activity test against murine leukemia cancer cells P-388 showed that the ester compound has good activity with an $\mathrm{IC}_{50}$ of $2.79 \mu \mathrm{g} / \mathrm{ml}$ and much better stability during storage compared to artonin E itself.
\end{abstract}

Keywords: A. rigida; artonin E acetate; esterification; anticancer activity

\begin{abstract}
ИЗОЛАЦИЈА НА АРТОНИН Е ОД КОРАТА НА КОРЕНОТ НА ARTOCARPUS RIGIDA, СИНТЕЗА НА АРТОНИН Е АЦЕТАТ И ОЦЕНУВАЊЕ НА АНТИКАНЦЕГЕНОТО ДЕЈСТВО
\end{abstract}

Артонин Е беше изолиран од кората на коренот на A. rigida. Изолираното соединение потоа беше естерифицирано со примена на позната постапка со додавање на анхидрид на оцетна киселина со пиридин како катализатор. Структурата на синтетизираното соединение беше внимателно определена со физички и спектроскопски техники и споредена со податоци од литературата. Тестот на антиканцерогеното дејство против леукогени канцерогени клетки Р-388 покажа дека естерското соединение добро дејствува со $\mathrm{IC}_{50}$ од $2,79 \mu \mathrm{g} / \mathrm{ml}$ и многу подобра стабилност при складирање споредено со самиот артонин Е.

Клучни зборови: A. rigida; артонин Е; естерификација; антиканцерогено дејство

\section{INTRODUCTION}

Some flavonoid compounds have been isolated from some species of Artocarpus and some of the compounds isolated have shown interesting biological activities [1-6]; one of the compounds is artonin E. Artonin E is a flavonoid compound which potential anticancer and antimalaria activity $[7,8]$ and can easily be isolated from various Artocarpus plant such as A. communis, A. rotunda, A. altilis, A. elasticus and A. rigida [3, 4, 7, 9-12].
As a flavone compound, artonin $\mathrm{E}$ has four hydroxyl groups. Two of these are in the ortho position, which makes them easily oxidized. One of the ways to protect the oxidation reaction occurring at these hydroxyl groups is by esterification.

In this work, artonin $\mathrm{E}$ was isolated from $A$. rigida, which is native of Indonesia. The plant was obtained from Keputran village, Sukoharjo, Pringsewu, Lampung, Indonesia. The artonin E was then esterified with acetic anhydride. The ester compound obtained was well characterized by physical 
and spectroscopic techniques and then tested for bioactivity against murine leukemia cancer cells P-388.

\section{EXPERIEMENTAL}

\subsection{General}

Melting points were determined with a Gallenkamp melting point apparatus and are uncorrected. The UV-vis and IR spectra were measured with Agilent Cary 100 and Agilent Cary 620 FTIR spectrophotometers, respectively. The ${ }^{1} \mathrm{H}$ and ${ }^{13} \mathrm{C}$ NMR spectra were obtained with an Agilent spectrometer with DD2 console system at $500 \mathrm{MHz}$ and $125 \mathrm{MHz}$, respectively. Vacuum liquid chromatography (VLC) was performed using a Merck Si-gel 60, and thin layer chromatography (TLC) analysis was carried out on pre-coated Si-gel plates (Merck Kieselgel 60 F254, 0.25 mm).

\subsection{Plant collection}

Samples of the root bark of A. rigida Blume were collected from Keputran village, Sukoharjo Pringsewu Lampung, in August 2015 and were identified at the Herbarium Bogoriense, Research Centre for Biology, Indonesia, Institute of Sciences Bogor, Indonesia and a voucher specimen has been deposited at the herbarium.

\subsection{Extraction and isolation}

The powder of root bark of $A$. rigida $(3 \mathrm{~kg})$ was extracted exhaustively with $n$-hexane and a mixture of methanol-ethyl acetate (EtOAc) 1:1 for 3 days for each process. Removal of the solvents by vacuum rotatory evaporator produced methanol/EtOAc extract $(150.9 \mathrm{~g})$. The methanol/EtOAc extract was then fractionated by Si-gel VLC eluted with EtOAc/ $n$-hexane in the ratio $0-100 \%$, to produce six main fractions (A-F). Fraction B weighed $38.7 \mathrm{~g}$ and fraction $\mathrm{C} 23.8 \mathrm{~g}$. Fractions $\mathrm{B}$ and $\mathrm{C}$ were then subjected again to VLC using Si-gel with the same eluent system. The result of fractionation was a yellow solid, which was recrystallized to produce yellow crystals (1.6343 g) with m.p. 250 $252^{\circ} \mathrm{C}$ and the same Rf with three eluent systems.

\subsection{Esterification of artonin $E$}

The isolated artonin E was then esterified using the method employed by Hano [9] as follows: $9.5 \mathrm{mg}$ artonin $\mathrm{E}$ was placed in a reaction tube and reacted $0.3 \mathrm{ml}$ acetic anhydride in the presence of $0.1 \mathrm{ml}$ of pyridine catalyst. The reac- tion mixture was then left in the sealed reaction tube for $72 \mathrm{~h}$. Every $24 \mathrm{~h}$ the purified product was tested with TLC. After $72 \mathrm{~h}$, the reaction mixture was added to $\mathrm{H}_{2} \mathrm{O}$, so the clear mixture became cloudy and formed clumps. The cloudy solution was then filtered off and vacuumed to produce white crystals and recrystallized in $n$-hexane/ether.

Artonin $\mathrm{E}$ was found as yellow crystals, m.p. $250-252{ }^{\circ} \mathrm{C}$, UV-vis $(\mathrm{MeOH}) \lambda_{\max }: 211,268$, and $347 \mathrm{~nm}$.

Ester of Artonin $\mathrm{E}$ acetate $\mathbf{1}$ was found as clear crystals, m.p. $190-192{ }^{\circ} \mathrm{C}$, UV-vis $(\mathrm{MeOH})$ $\lambda_{\max }: 211,236$ (shoulder), 261 and 319. IR (KBr) $v_{\text {max. }}: 3343$ (wide), 2918, 1770, 1635, 1573, 1492, $1421,1373,1283,1226$ and $1081 \mathrm{~cm}^{-1}$.

${ }^{1} \mathrm{H}$ NMR $\left(\mathrm{CDCl}_{3}\right) \delta(\mathrm{ppm}): 1.36(\mathrm{H}-13)$; 1.46 (H-17 and $\mathrm{H}-18) ; 1.57$ (H-9); 1.58 (H-12); $2.11 ; 2.31 ; 2.32 ; 2.44$ (four $\mathrm{CH}_{3}$ groups from acetyl group); 5.05 (H-10); $5.62(\mathrm{H}-15) ; 6.47$ (H-6); 6.62 (H-14); $7.22\left(\mathrm{H}^{\prime} 3^{\prime}\right)$ and 7.28 (H-6').

${ }^{13} \mathrm{C}$ NMR $\left(\mathrm{CDCl}_{3}\right) \delta$ (ppm): 17.64; 20.71; $20.85 ; 20.98 ; 21.44 ; 24.48 ; 25.71 ; 28.46 ; 78.44$; $107.57 ; 109.28 ; 110.38 ; 114.78 ; 118.98 ; 121.14$; $123.73 ; 123.91 ; 125.11 ; 129.78 ; 132.58 ; 139.57$; $143.78 ; 146.03 ; 149.76 ; 153.11 ; 155.47 ; 157.14$; $167.6 ; 167.8 ; 168.6$ and 176.08 .

\subsection{Bioactivity}

The bioactivity test performed was a cytotoxicity test of compound $\mathbf{1}$ based on the method of Alley et al. [13] and was conducted at Laboratory of Natural Product Chemistry, Department of Chemistry, Bandung Institute of Technology, Bandung, Indonesia. Leukemia cancer cells P-388 were supplied by Dr. S Tsukagoshi of the Japan Foundation for Cancer Research and were kept on RPMI-1640 media (Nissui Pharm. Co., Ltd) with 5\% fetal calf serum (Mitsubishi Chemical Industry Co., Ltd.) and kanamycin $(100 \mu \mathrm{g} / \mathrm{ml})$. The cancer cells $\left(3 \times 10^{3}\right.$ cells/well) were cultured on 96 -well Corning disposable plates containing $100 \mu \mathrm{l}$ growth media and incubated at $37^{\circ} \mathrm{C}$ with an atmosphere of $5 \% \mathrm{CO}_{2}$. Samples $(10 \mu \mathrm{l})$ with various concentrations of the tested compound were added to the culture one day after transfer. On the third day, $20 \mu \mathrm{l}$ of MTT solution $(5 \mathrm{mg} / \mathrm{ml})$ per well was added to each culture medium. After $4 \mathrm{~h}$ of incubation, $100 \mathrm{ml}$ of $10 \%$ SDS solution in $0.01 \mathrm{~N} \mathrm{HCl}$ was added to each well and formazan crystals were dissolved in each well by stirring with a pipette. The optical density measurement was performed with a Tohso MPR-A4i microplate reader using two wavelength systems (550 and $700 \mathrm{~nm}$ ). For all experiments, three replicates were conducted to determine each test point. 


\section{RESULTS AND DISCUSSION}

\subsection{Spectroscopic analyses}

Artonin E acetate 1, the product of esterification of artonin $\mathrm{E}$ with acetic anhydride, was carefully analyzed based on the spectroscopic data. The data from UV-vis (Fig. 1), IR (Fig. 2), ${ }^{1} \mathrm{H}$ NMR (Fig. 3) and ${ }^{13} \mathrm{C}$ NMR (Fig. 4) of compound 1 were compared to the data for isolated artonin $\mathrm{E}$.

Table 1 shows the comparison of ${ }^{1} \mathrm{H}$ NMR data of artonin E tetraacetate [9] and compound 1 The data clearly suggest that the esterification of artonin E was successfully achieved although there are slightly changes in the chemical shifts, which might be due to the different solvents used in the measurements.

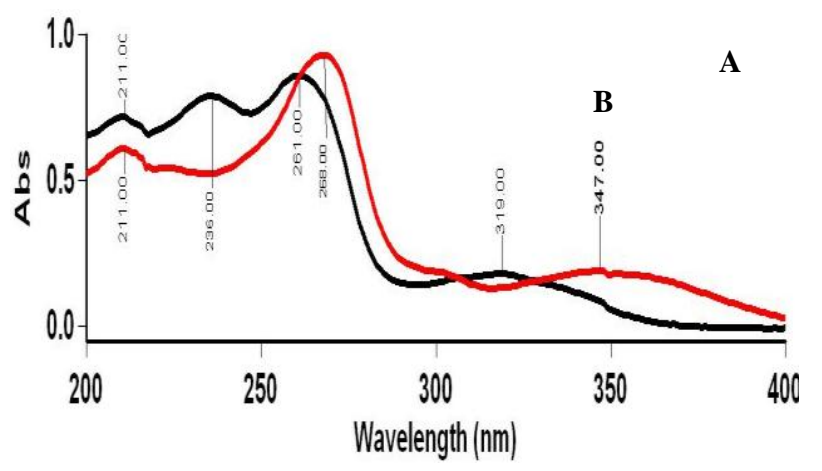

Fig. 1. UV-vis spectra of (A) isolated artonin E; (B) the ester compound of artonin Eacetate (in methanol)
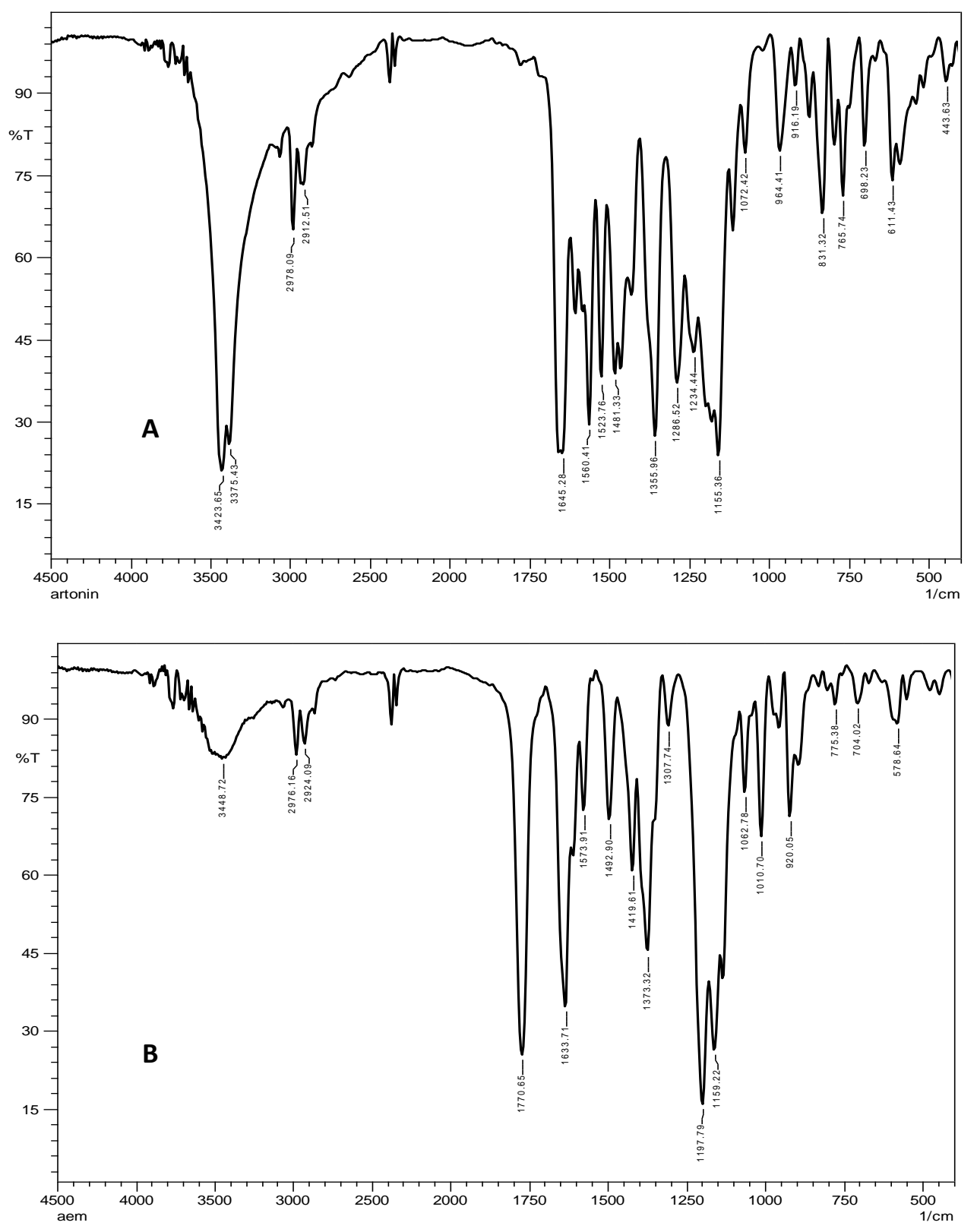

Fig. 2. The comparison of IR spectra of (A) isolated artonin E [7]; (B) compound 1 
Hernawan-aem_1H

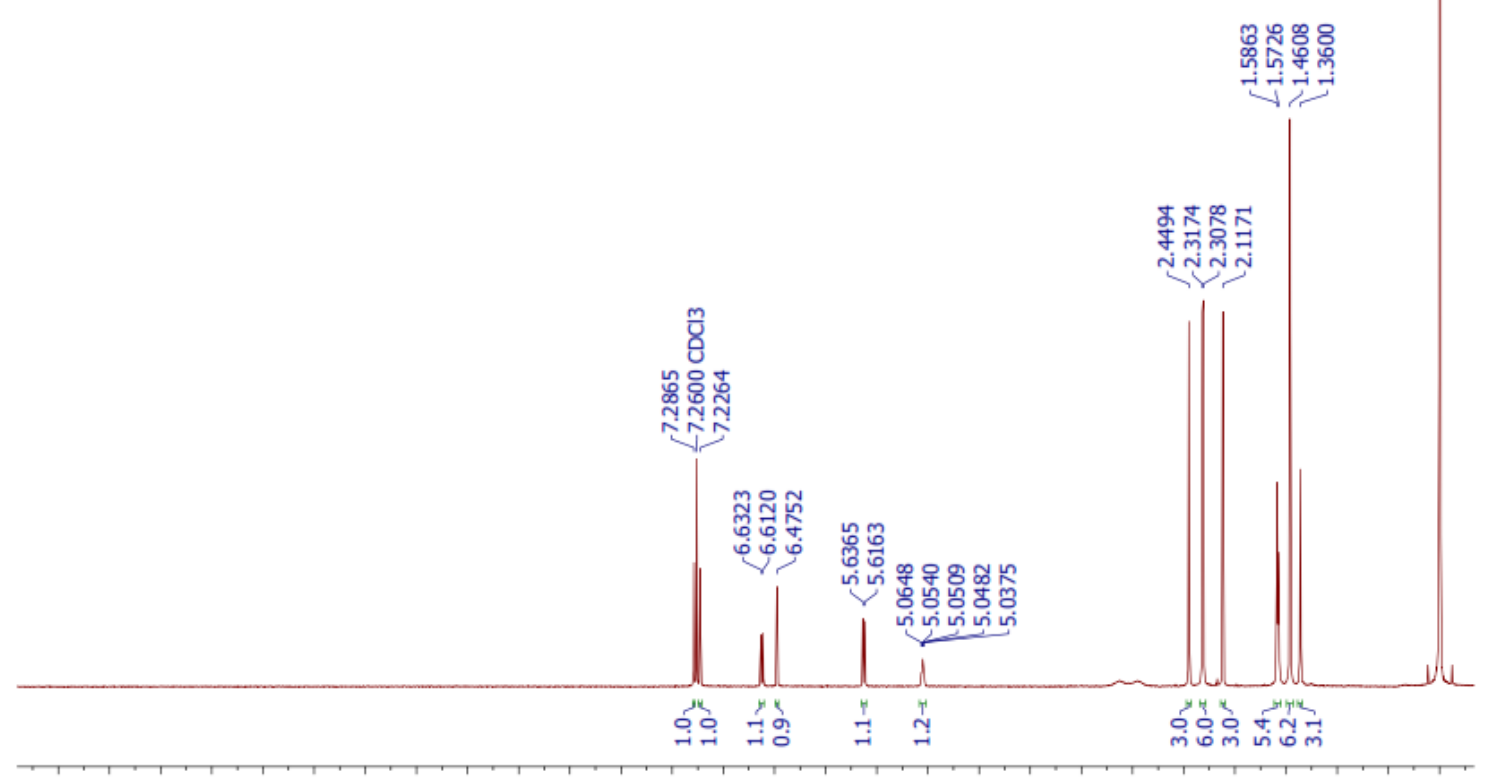

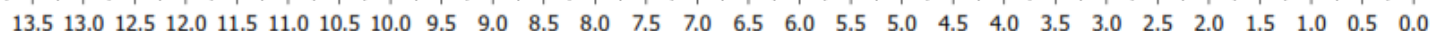

Fig. 3. ${ }^{1} \mathrm{H}$ NMR spectrum of compound 1

Hernawan-aem_13C

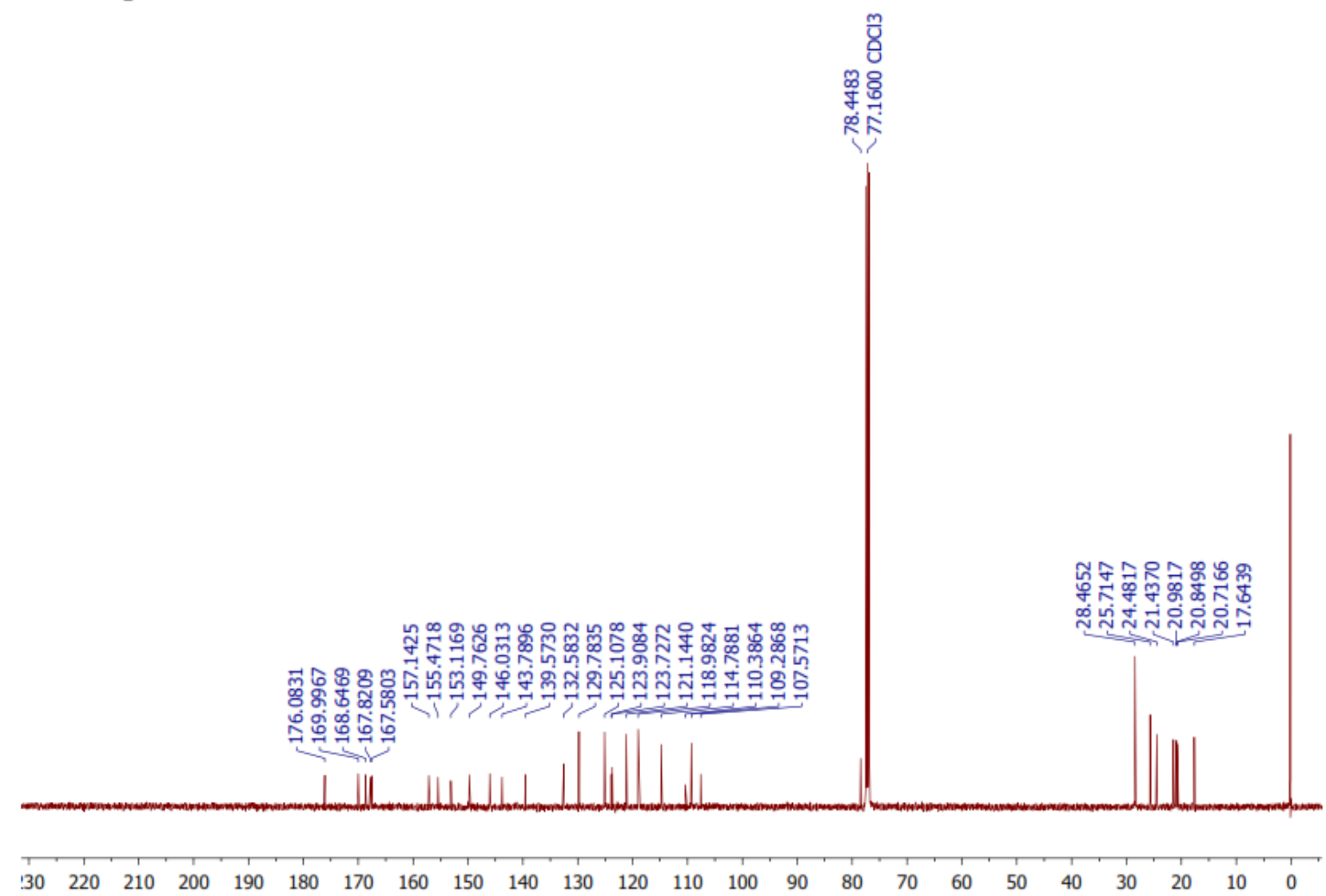

Fig. 4. ${ }^{13} \mathrm{C}$ NMR spectrum of compound 1 
Table 1

The comparison of ${ }^{1} H$ NMR data between artonin E tetraacetate [9] and compound 1

\begin{tabular}{|c|c|}
\hline \multicolumn{2}{|c|}{ 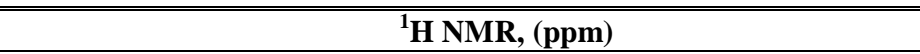 } \\
\hline (2) $\left(\right.$ DMSO-d $\left._{6}\right)$ & (1) $\left(\mathrm{CDCl}_{3}\right)$ \\
\hline 1.28 (3H. s. C-11-CH $\left.{ }_{3}\right)$ & 1.36 (3H. s. C-11-CH $\left.{ }_{3}\right)$ \\
\hline 1.45 (6H. s. C-16- $\mathrm{CH}_{3}$ x2) & 1.46 (6H. s. C-16- $\mathrm{CH}_{3}$ x2) \\
\hline $\begin{array}{l}3.32 \\
\left(2 \mathrm{H} \text {, overlapping } \mathrm{H}_{2} \mathrm{O} \text { signal. } \mathrm{C}-9-\mathrm{H}\right)\end{array}$ & 1.57 (2H. d. C-9-H) \\
\hline 1.53 (3H. s. C- $\left.11-\mathrm{CH}_{3}\right)$ & 1.58 (3H. s. C- $\left.11-\mathrm{CH}_{3}\right)$ \\
\hline $2.10\left(3 \mathrm{H} . \mathrm{s} . \mathrm{COCH}_{3}\right)$ & 2.11 (3H. s. $\left.\mathrm{COCH}_{3}\right)$ \\
\hline 2.32 (6H. s. $\left.\mathrm{COCH}_{3} \times 2\right)$ & $2.32\left(3 \mathrm{H} . \mathrm{s} . \mathrm{COCH}_{3}\right)$ \\
\hline & 2.31 (3H. s. $\left.\mathrm{COCH}_{3}\right)$ \\
\hline 2.33 (3H. s. $\left.\mathrm{COCH}_{3}\right)$ & 2.44 (3H. s. $\left.\mathrm{COCH}_{3}\right)$ \\
\hline 4.92 (1H. m. C-10-H) & 5.05 (1H. m. C-10-H) \\
\hline 5.87 (1H. d. $J=10 \mathrm{~Hz} . \mathrm{C}-15-\mathrm{H})$ & $5.62(1 \mathrm{H}$. d. $J=10 \mathrm{~Hz} . \mathrm{C}-15-\mathrm{H})$ \\
\hline $6.53(1 \mathrm{H}$. dd. $J=0.6 \& 10 \mathrm{~Hz}$ C-14-H) & $6.62(1 \mathrm{H}$. d. $J=10 \mathrm{~Hz} \mathrm{C}-14-\mathrm{H})$ \\
\hline 6.65 (1H. d. $J=0.6$ Hz. C-6-H) & 6.47 (1H. s. C-6-H) \\
\hline 7.45 (1H. s. C-3'-H) & 7.22 (1H. s. C-3'-H) \\
\hline 7.61 (1H. s. H-6'-H) & 7.28 (1H. s. H-6'-H) \\
\hline
\end{tabular}

Table 2

The comparison of ${ }^{13} \mathrm{C}$ NMR data between artonin E tetraacetate [9] and compound 1

\begin{tabular}{|c|c|c|}
\hline \multicolumn{3}{|c|}{ 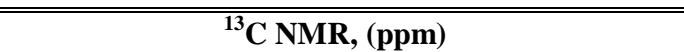 } \\
\hline No C & (2) DMSO-d6 & (1) $\mathrm{CDCl}_{3}$ \\
\hline 2 & 162.20 & 155.47 \\
\hline 3 & 121.70 & 123.91 \\
\hline 4 & 183.30 & 176.08 \\
\hline $4 a$ & 105.60 & 110.38 \\
\hline 5 & 162.80 & 149.76 \\
\hline 6 & 99.70 & 109.28 \\
\hline 7 & 160.00 & 157.14 \\
\hline 8 & 101.60 & 107.57 \\
\hline $8 a$ & 153.30 & 153.11 \\
\hline 1 ' & 111.60 & 123.73 \\
\hline 2 , & 149.80 & 146.03 \\
\hline 3, & 104.80 & 125.11 \\
\hline 4 , & 149.50 & 143.78 \\
\hline 5 , & 139.10 & 139.57 \\
\hline 6 ' & 117.10 & 118.98 \\
\hline 9 & 24.70 & 21.44 \\
\hline 10 & 122.50 & 121.14 \\
\hline 11 & 132.30 & 132.58 \\
\hline 12 & 25.80 & 25.71 \\
\hline 13 & 17.70 & 17.64 \\
\hline 14 & 115.50 & 114.78 \\
\hline 15 & 128.00 & 129.78 \\
\hline 16 & 78.80 & 78.44 \\
\hline 17 & 28.30 & 28.46 \\
\hline 18 & 28.30 & 28.46 \\
\hline \multicolumn{3}{|l|}{$\mathrm{CH}_{3} \mathrm{CO}$} \\
\hline $\mathbf{C}=\mathbf{O}$ & & $\begin{array}{r}178.0 ; 168.6 ; 167.8 ; \\
167.6\end{array}$ \\
\hline $\mathrm{CH}_{3}$ & & $24.48 ; 20.71 ; 20.98 ;$ \\
\hline
\end{tabular}

The comparison of ${ }^{13} \mathrm{C}$ NMR data between artonin E tetraacetate [9] and compound $\mathbf{1}$ can be seen in Table 2.

The binding of hydrogen atoms to certain carbon atoms in compound $\mathbf{1}$ is shown by the heteronuclear single quantum correlation (HSQC) spectrum as can be seen in Table 3. The HSQC technique normally provides information about the correlation between the proton and the carbon in a single bond [14].

The relative position of hydrogen atoms and the two isoprenyl substituents on the flavone carbon frame is shown by the heteronuclear multiple bond correlation (HMBC) of compound $\mathbf{1}$, as shown in Figure 5.

Table 3

The HSQC spectrum data of compound 1

\begin{tabular}{ccc}
\hline \hline No C & ${ }^{\mathbf{1}} \mathbf{H}$ NMR, $\mathbf{p p m}$ & ${ }^{\mathbf{1 3}} \mathbf{C}$ NMR, $\mathbf{p p m}$ \\
\hline 6 & 6.47 & 109.28 \\
10 & 5.05 & 121.14 \\
12 & 1.58 & 25.71 \\
13 & 1.36 & 17.64 \\
14 & 6.62 & 114.78 \\
15 & 5.62 & 129.78 \\
17 & 1.46 & 28.46 \\
18 & 1.46 & 28.46 \\
3 & 7.22 & 125.12 \\
6 & 7.28 & 118.98 \\
\hline \hline
\end{tabular}




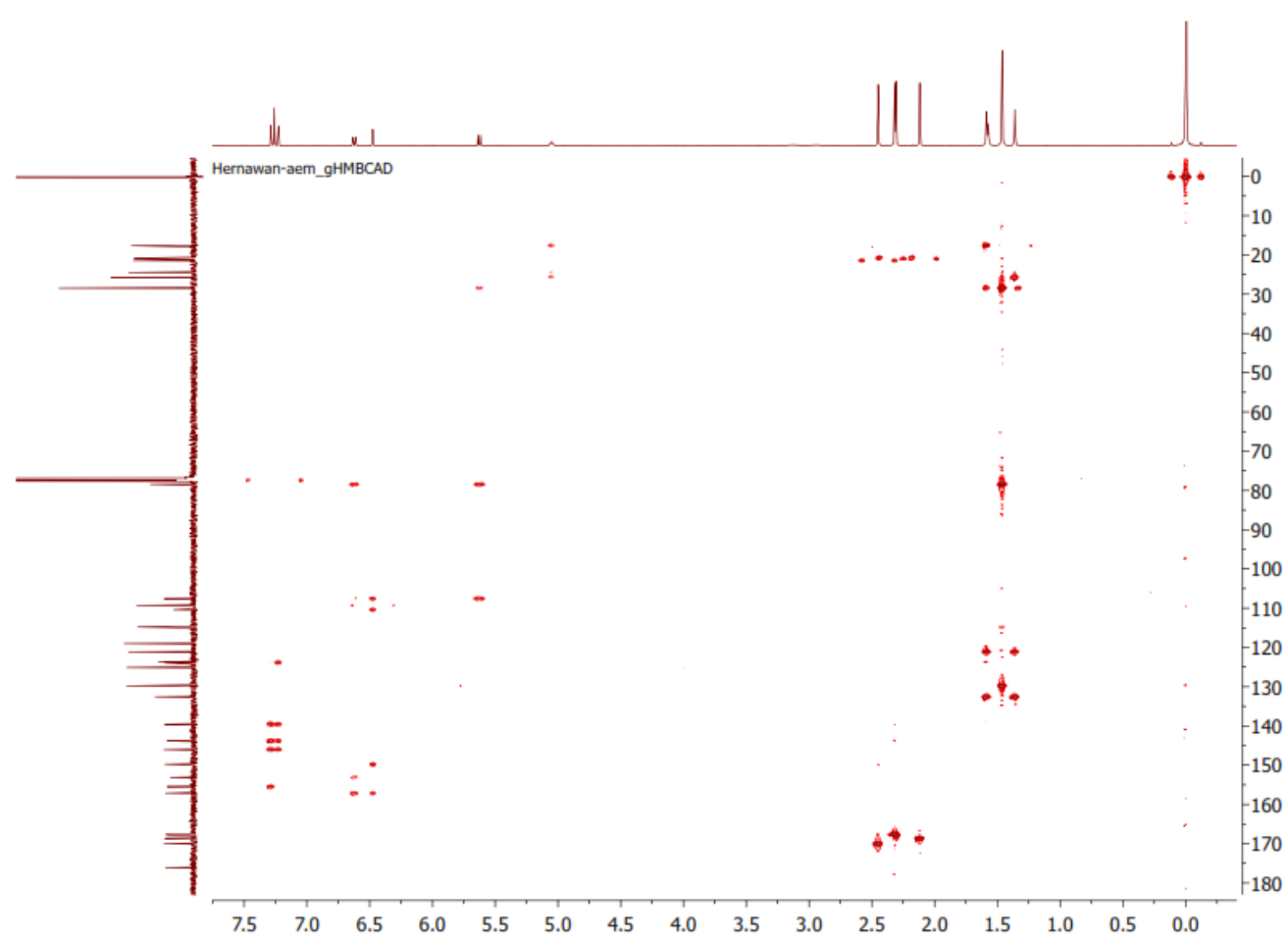

Fig. 5. Correlation spectrum of heteronuclear multiple bond correlation (HMBC) of compound 1

There are four ester groups in artonin $\mathrm{E}$ and the use of $\mathrm{CDCl}_{3}$ solvent causes the multiple bond correlation of carbonyl on $\mathrm{C}-4$ and hydrogen to not appear in the HMBC spectrum. However, based on the analysis of the HMBC spectrum, the structure of compound $\mathbf{1}$ is as shown in Figure 6.

The UV-vis spectraof the isolated artonin $\mathrm{E}$ showed maximum absorbances at $\lambda_{\max } 211,268$, and $347 \mathrm{~nm}$ in methanol with solution concentration of $5 \mathrm{ppm}(1 \mathrm{mg} / 20 \mathrm{~mL})$. The UV spectrum of artonin $\mathrm{E}$ shows absorbances characteristic of a flavone compound. The maximum absorbance at $\lambda_{\max } 347 \mathrm{~nm}$ is specific flavone absorption of a band I cinnamoyl group, which indicates the presence of free hydroxyl groups on the flavonoid B ring. The maximum absorbance at $\lambda_{\max } 267 \mathrm{~nm}$ is a specific absorption of flavone on band II and is characteristic of a benzoyl group on the A ring. The absorbances of compound 1 were at $\lambda_{\max } 211$, 236 (shoulder) and $319 \mathrm{~nm}$ in methanol at a concentration of $10 \mathrm{ppm}(1 \mathrm{mg} / 10 \mathrm{ml})$.

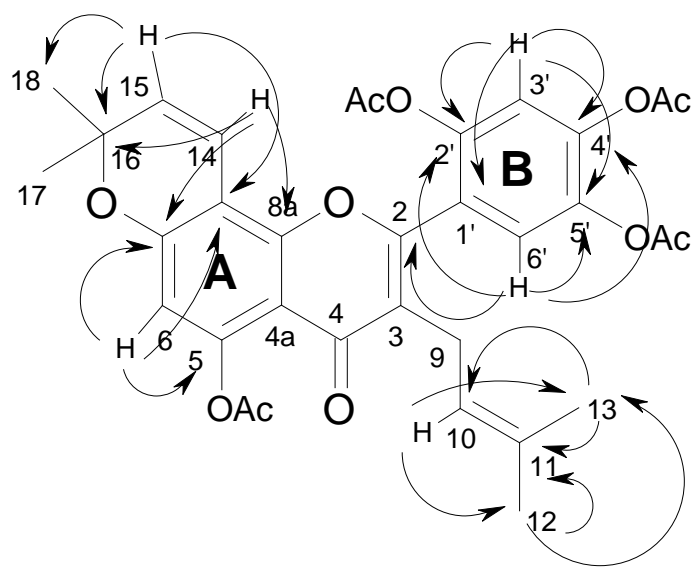

Fig. 6. The important structure correlation of compound $\mathbf{1}$ based on the HMBC spectrum 
The UV spectrum of compound 1 still shows absorbances characteristic of a flavone. The maximum absorbances of $\mathbf{1}$ with $\lambda_{\max } 319$ and $261 \mathrm{~nm}$ show changes in the $\mathrm{B}$ ring and $\mathrm{A}$ ring of artonin E, since there are absorption decreases of $28 \mathrm{~nm}$ on band I and $7 \mathrm{~nm}$ on band II. The decrease of absorption on band I indicates that the free hydroxyl group of artonin $\mathrm{E}$ on the $\mathrm{B}$ ring has been esterified by acetic anhydride. The same observation also occurred on the $\mathrm{B}$ ring where the maximum absorbance decreased by $7 \mathrm{~nm}$, indicating that the hydroxyl group at $\mathrm{C}-5$ on the A ring had also been esterified.

The success in the esterification reaction was also supported by the IR spectrum of $\mathbf{1}$, where the transmittance intensity of the $-\mathrm{OH}$ vibration at $3423 \mathrm{~cm}^{-1}$ and hydrogen bonding between carbon$\mathrm{yl}$ and the $-\mathrm{OH}$ group on $\mathrm{C}-5$ is no longer observed, as shown by the vibration change of the carbonyl group of artonin E at $1645 \mathrm{~cm}^{-1}$ (the spectrum obtained for artonin $\mathrm{E}$ is identical to that reported previously by Suhartati et al. [7]) to 1770 $\mathrm{cm}^{-1}$ for compound $\mathbf{1}$. The comparison of the IR spectra of artonin E and $\mathbf{1}$ is shown in Figure 2.

Figure 3 shows the ${ }^{1} \mathrm{H}$ NMR spectrum of compound $\mathbf{1}$. Three singlets at chemical shift $(\delta)$ of $1.28,1.46\left(2 \times \mathrm{CH}_{3}\right)$ and $1.58 \mathrm{ppm}$ from the four $\mathrm{CH}_{3}$ groups are observed. The multiplet peaks appear at $\delta 5.03 \mathrm{ppm}(1 \mathrm{H}, \mathrm{m})$ due to the two neighboring protons having different chemical shifts. The doublet peaks of $\mathrm{sp}^{2}$ carbon appear at $\delta 5.62$ and $6.62 \mathrm{ppm}(1 \mathrm{H}, \mathrm{d}, J=10 \mathrm{~Hz})$ from the two neighboring protons of the alkene carbon. In the proton shift region of $\mathrm{sp}^{2}$ aromatic carbon, there are two singlet protons with $\delta 7.22 \mathrm{ppm}$ and $7.28 \mathrm{ppm}$ from the protons on the $\mathrm{B}$ ring, which indicates that $\mathrm{C}-2^{\prime}, \mathrm{C}-4^{\prime}$ and $\mathrm{C}-5^{\prime}$ ' are containing oxygen atom [15].
The singlet proton of one proton on the A ring appears at $\delta 6.47 \mathrm{ppm}$. The specific differences between artonin $\mathrm{E}$ and compound $\mathbf{1}$ are the appearance of singlet peaks at $\delta 2.11,2.31,2.32$ and $2.44 \mathrm{ppm}$, indicating the presence of four methyl groups from the ester of artonin E acetate [16].

The success of esterification is strengthened by ${ }^{13} \mathrm{C}$ NMR spectrum of compound 1 (Figure 4) which shows the presence of 33 carbon atoms, where some of them show the appearance of $\mathrm{C}$ carbonyl at chemical shifts of $\delta 176.08$ (C-4), $169.99,168.64,167.82$ and $167.58 \mathrm{ppm}$, wher the last four signals are from the carbonyls of four acetyl groups, and also the chemical shifts at 20.71 20.8420 .98 and $21.43 \mathrm{ppm}$ due to the presence of four methyl groups of the acetyl group.

\subsection{Anticancer activity test}

The cytotoxicity test using murine leukemia cancer cells P-388 showed that compound $\mathbf{1}$ was active, with an $\mathrm{IC}_{50} 2.79 \mu \mathrm{g} / \mathrm{ml}$. The determination of $\mathrm{IC}_{50}$ was processed from the data in Table 4 using Origin 8.5 software, as shown in Figure 7.

According to Suhartati et al. [10], artonin E shows much higher activity with an $\mathrm{IC}_{50}$ of 0.06 $\mu \mathrm{g} / \mathrm{ml}$; however, artonin $\mathrm{E}$ is less stable towards oxidation. Compound $\mathbf{1}$ is more stable compared to artonin $\mathrm{E}$. This is because artonin $\mathrm{E}$ is easily oxidized due to the presence of two ortho hydroxy groups on the B ring; thus, although the activity of artonin $\mathrm{E}$ is higher, the stability is very low, while compound 1 still shows excellent anticancer activity [8], with good stability. The results obtained indicate that compound $\mathbf{1}$ is potentially useful as a future drug in the treatment of cancer, since it is very stable and can thus be stored for longer period than can artonin $\mathrm{E}$.

Ta ble 4

P-388 test data of compound $\mathbf{1}$

\begin{tabular}{|c|c|c|c|c|c|}
\hline \multicolumn{5}{|c|}{ Optical density of compound (1) } & $\begin{array}{c}\text { The average optical } \\
\text { density of (1) }\end{array}$ \\
\hline 100 & & 0.013 & 0.01 & 0.016 & 0.013 \\
\hline 30 & & 0.01 & 0.005 & 0.01 & 0.008333 \\
\hline 10 & & 0.012 & -0.004 & 0.001 & 0.003 \\
\hline 3 & & 0.056 & 0.074 & 0.043 & 0.057667 \\
\hline 1 & & 0.828 & 0.803 & 0.659 & 0.763333 \\
\hline 0.3 & & 0.705 & 0.633 & 0.636 & 0.658 \\
\hline 0.1 & & 0.542 & 0.743 & 0.671 & 0.652 \\
\hline $\begin{array}{c}\text { Positive blank } \\
0.573\end{array}$ & 0.628 & 0.649 & 0.629 & 0.603 & $\begin{array}{r}100 \% \\
0.609667\end{array}$ \\
\hline
\end{tabular}




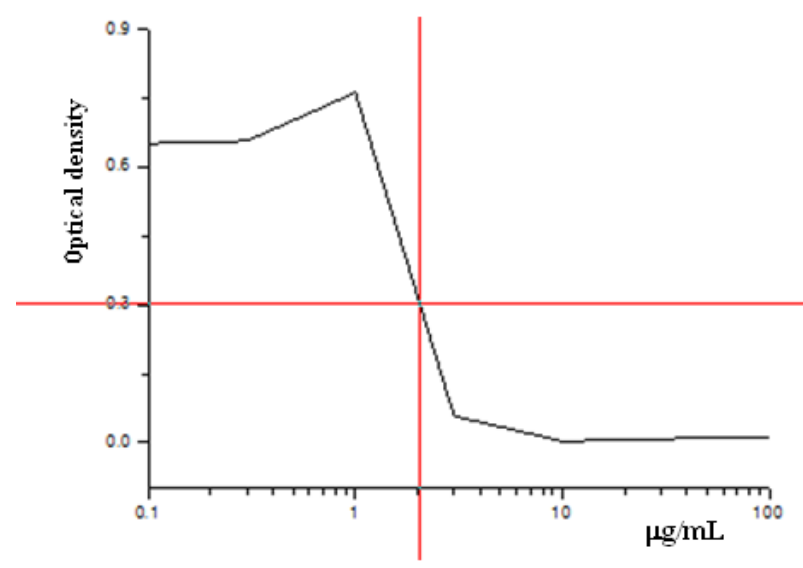

Fig. 7. The graph of cytotoxicity test of compound 1 using leukemia cells P-388

\section{CONCLUSIONS}

Artonin E has been successfully isolated from the root bark of $A$. rigida and has also been modified to an ester: artonin $\mathrm{E}$ acetate. The synthesized compound has been shown to have excellent anticancer activity against murine cancer cells P388 with an $\mathrm{IC}_{50}$ of $2.79 \mu \mathrm{g} / \mathrm{ml}$.

Acknowledgments: The authors are grateful to the Directorate of Research and Community Services, the Directorate General of Higher Education, and the Ministry of Research, Technology and Higher Education, Republic of Indonesia, who provided funds for this project to be undertaken through Hibah Kompetensi (Competitive Research Grant) Scheme 2017 with contract number 582/UN26.21/KU/2017, 7 June 2017.

\section{REFERENCES}

[1] T. Nomura, S. Hano, M. Aida, Isoprenoid-Substituted Flavonoid from Artocarpus Plants (Moraceae), Heterocycles, 47, 1179-1205 (1998).

[2] B. N. Su, M. Cuendet, M. E. Hawthorne, L. B. S. Kardono, S. Riswan, H. H. S. Fong, R. G. Mehta, J. M. Pezzuto, A. D. Kinghorn, Constituents of the bark and twigs of Artocarpus dadah with cyclooxygenase inhibitory activity, J. Nat. Prod., 65, 163-169 (2002).

[3] A. R. Han, Y. J. Kang, T. Wibowo, S. K. Lee, E. K. Seo, Prenylated flavonoids from the heartwood of Artocarpus communis with inhibitory activity on lipopolysaccharide induced nitric oxide production, J. Nat. Prod., 69, 719721 (2006).
[4] Y. Ren, L. B. S. Kardono, S. Riswwan, H. Chai, N. R. Farnsworth, D. D. Soerjarto, E. J. de Blanco, A. D. Kinghorn, Cytotoxic and NF- $\mathrm{BB}$ inhibitory constituents of Artocarpus rigida, J. Nat. Prod., 75, 949-955 (2010).

[5] M. T. T. Nguyen, T. H. Le, H. X. Nguyen, P. H. Dang, T. N. V. Do, M. Abe, R. Takagi, N. T. Nguyen, Artocarmins G-M, Prenylated 4-Chromenones from the Stems of Artocarpusrigida and Their Tyrosinase Inhibitory Activities, J. Nat. Prod., 80, 3172-3178 (2017).

[6] T. Suhartati, A. Wulandari, J. F. Suwandi, Yandri, S. Hadi, Artonin O, a Xanthone Compound from Root Wood of Artocarpus rigida, Orient. J. Chem., 32 (5), 2777-2784, (2016).

[7] T. Suhartati, Yandri, S. Hadi, The Bioactivity Test of Artonin E from the Bark of Artocarpus rigida Blume, Eur. J. Sci. Res., 23, 330-337 (2008).

[8] T. Suhartati, Yandri, J.F Suwandi, S. Hadi, In vitro and in vivo antiplasmodial activity of oxyresveratrol and artonin E isolated form two Artocarpus plants in Indonesia,. Orient. J. Chem., 26 (3), 825-830 (2010).

[9] Y. Hano, Y. Yamagami, M. Kobayashi, R. Isohata, T. Nomura ,Artonins E and F, Two New Prenylflavones From The Bark of Artocarpus communis Forst, Heterocycles, 31, 877-882 (1990).

[10] T. Suhartati, S. A. Achmad, N. Aimi, E. H. Hakim, M. Kitajima, H. Takayama, K. Takeya, Artoindonesianin L, a new prenylated flavone with cytotoxicity activity from Artocarpus rotunda, Fitoterapia, 72, 912-918 (2001).

[11] S. Boonphong, A. Baramee, P. Kittakoop, P. Puangsombat, Antitubercular and Antiplasmodial prenylated flavones from the roots of Artocarpus altilis, Chiang Mai J. Sci., 34(3), 339-344 (2007).

[12] I. Etti, R. Abdullah, N. M. Hashim, A. Kadir, A. B. Abdul, C. Etti, I. Malami, P. Waziri and C. Wun, How Artonin E and Structural Analogs from Artocarpus Species Abrogates Estrogen Receptor Signaling in Breast Cancer, Molecules, 21(7), 839-856 (2016).

[13] M. C Alley, D. A. Scudiero, A. Monks, M. L. Hursey, M. J. Czerwinski, D. L. Fine, B. J. Abbott, J. G. Mayo, R. H. Shoemaker, M. R. Boyd, Feasibility of drug screening with panels of human tumor cell lines using a microculture tetrazolium assay, Cancer Res., 48, 589-601 (1988).

[14] E. Breitmaier, Structure Elucidation by NMR in Organic Chemistry. A Practical Guide. Third Revised Edition. John Wiley \& Sons Ltd., England, 2002, 258 p.

[15] F. A. Settle, Handbook of Instrumental Techniques for Analytical Chemistry. Prentice-Hall, Inc., New Jersey, 1997. p. 25-30; 247-252; 309-311; 481-485.

[16] T. J. Mabry, K. R Markham, M. B. Thomas, The Systematic Identification of Flavonoid. Spinger-Verlag, New York, 1970. p. 3-56, 165-171. 